\title{
Simplified 1D Empirical Model for Volumetric Behavior of High-Carbonate Clay
}

Vázquez-Boza, Manuel; Justo Alpañés, José Luis; Durand, Percy; Delgado Trujillo, Antonio; Justo Moscardó, Enrique (2019). International Journal of Geomechanics, (19) 4: 04019018.

This is the final Draft Manuscript.

This material may be downloaded for personal use only. Any other use requires prior permission of the American Society of Civil Engineers. This material may be found at https://ascelibrary.org/doi/10.1061/\%28ASCE\%29GM.1943-5622.0001359 


\section{A simplified 1-D empirical model for volumetric behaviour of high carbonate clay}

3

5

6

Manuel Vázquez-Boza, Ph.D. ${ }^{1}$; José Luis Justo, Ph.D.'; Percy Durand, Ph.D.; Antonio Delgado, Ph.D. ${ }^{4}$; and Enrique Justo, Ph.D. ${ }^{5}$.

${ }^{I}$ Department of Building Structures and Ground Engineering, E.T.S Architecture, University of Seville, Spain (corresponding author). E-mail: mboza@us.es.

${ }^{2}$ Professor Emeritus, Department of Building Structures and Ground Engineering, E.T.S Architecture, University of Seville; President, Royal Academy of Sciences of Seville, Spain. E-mail: jlj@us.es.

${ }^{3}$ Department of Building Structures and Ground Engineering, E.T.S Architecture, University of Seville, Spain. E-mail: percy@us.es.

${ }^{4}$ Department of Building Structures and Ground Engineering, E.T.S Architecture, University of Seville, Spain.E-mail: antoniodelga@us.es.

${ }^{5}$ Department of Building Structures and Ground Engineering, E.T.S Architecture, University of Seville, Spain.E-mail: ejem@us.es.

Abstract: The Guadalquivir blue marl is a high plasticity overconsolidated carbonate clay. This soil presents an elevated fragility and high susceptibility to moisture changes. These characteristics have caused many geotechnical accidents, such as the Aznalcollar dam failure, in Seville (Spain). A comprehensive test campaign has been conducted to determine the physical and chemical properties of the blue marl. Analysis by scanning electron microscopy (SEM) and mercury intrusion porosimetry (MIP) allowed characterising its internal structure, revealing clear differences between the macro and the microstructure. A novel model for predicting the volumetric deformation (under oedometric conditions) of the Guadalquivir blue marl with suction and vertical pressure changes has been proposed. The model, based on data from shrink-swell tests, provides an acceptable estimation of the volumetric behaviour of the soil with a relatively simple set of parameters. The results were experimentally verified by suction-controlled oedometer tests and showed an acceptable agreement with the data measured. It has been specified when swelling. shrinkage or collapse occur. 
29 Author keywords: Blue marl, Volumetric deformation, 1D model, Suction, Unsaturated soil, 30 Guadalquivir River.

\section{Introduction}

The bedrock layer of the Guadalquivir River basin consists of a plastic, carbonated and overconsolidated clay, known as Guadalquivir blue marl. For geotechnical purposes, the thickness of this layer can be considered infinite. Although the blue marl is normally found in deep strata, it emerges superficially in some areas of the provinces of Huelva, Seville, Córdoba and Jaén (Tsige 1999).

This geological formation, of marine origin, was deposited in the Upper Miocene (Tortonian). The geotechnical characteristics of the blue marl include expansive behaviour, highly fragile shear strength and degradation after drying and wetting cycles, particularly in the shallowest zones (Alonso and Gens 2006a; Galera et al. 2009). These characteristics have caused significant damages to structures, pavements, dams and other constructions. Particularly remarkable are the slide at Almodóvar del Río, which damaged the Seville-Madrid high speed railway, and the Aznalcóllar dam failure, that caused one of the greatest environmental disasters in Spain's recent history (Alonso and Gens 2006a; Alonso and Gens 2006b; Gens and Alonso 2006; Zabala and Alonso 2011). The cost of repairing and mitigation measures associated with the problematic characteristics of the Guadalquivir blue marl (especially due to its expansive character) can be estimated at 28 million euros per year, afecting a total population of six million people (Llorente 1986).

For these reasons, predicting the deformational behaviour of this soil is a research topic of particular interest. In this paper, the effect of suction changes on the volumetric behaviour of the blue marl is analysed. A one-dimensional (1-D) model to predict the deformational behaviour of this type of soil, valid for swell and shrinkage strains, is presented.

Techniques for estimating the 1-D behaviour of expansive soils have been of great interest to academics and practitioners since they provide valuable information using a simple formulation, which makes them especially useful for engineering practice applications (Vanapalli and Lu 2012).

One of the first methods to estimate deformation changes with suction was proposed by Aitchison (1973) who established a linear relationship between volumetric strain and suction change in logarithmic scale, controlled by a coefficient called instability index $\left(I_{p t}\right)$.

$$
\varepsilon_{\mathrm{v}}=I_{\mathrm{pt}} \cdot \log \left(\Psi_{\mathrm{f}} / \Psi_{\mathrm{i}}\right)
$$


where $\varepsilon_{\mathrm{v}}$ is the volumetric strain (positive for compression), and $\Psi_{\mathrm{f}}$ and $\Psi_{\mathrm{i}}$ are the final and initial suctions.

Similar expressions were presented by McKeen (1980), based on previous work by Lytton (1977), Hamberg and Nelson (1984) and Dhowian (1990), using different names for the instability index. In some cases, the instability index was obtained through the COLE (Coefficient of Linear Extensibility) test developed by the US Soil Conservation Service (Brasher et al. 1966), the core shrinkage test (Mitchell and Avalle 1984) or indirectly through physicochemical parameters, such as the activity of clay or the cation exchange capacity (Pousada 1984).

Fredlund (1983) developed a model to predict the vertical displacements of the expansive soil of Regina (Canada). His formulation is also linear and relates the vertical displacements of the soil $(\Delta H)$ to the difference between the final effective pressure $\left(\sigma_{\mathrm{f}}^{\prime}\right)$ and the swelling pressure $\left(p_{\mathrm{s}}{ }_{\mathrm{s}}\right)$ in a logarithmic scale.

$$
\Delta H=C_{S} \cdot \frac{H}{1+e_{0}} \cdot \log \left(\frac{\sigma_{\mathrm{f}}}{p_{\prime}^{\prime}}\right)
$$

where $H$ is the thickness of the soil layer that has the potential to heave and $C_{\mathrm{s}}$ is the swelling index.

$$
\text { Fityus and Smith (1998) performed oedometric tests to a clay from Newcastle (Australia) under }
$$
overburden pressure under the assumption that a given variation in soil moisture produces a unique variation of deformation ratio, and generated a model (Eq. 7) valid for expansive and collapsing behaviour. In their model, the soil deformation was calculated as a function of the moisture increment through a linearity coefficient called volume change index $\left(I_{\mathrm{v}}\right)$, that was shown to have a linear relationship with the vertical pressure applied in the test.

$$
\Delta H=-0.33 \cdot H \cdot I_{v} \cdot\left(w_{f}-w_{i}\right)
$$

In this expression, $w_{\mathrm{f}}$ and $w_{\mathrm{i}}$ are the final and initial gravimetric moisture respectively, $H$ is the thickness of the soil layer analysed and $\Delta H$ is the vertical displacement in response to moisture change.

Vanapalli et al. (2010) proposed a model to evaluate the strain in under oedometric conditions of expansive soils after moisture changes, based on Eq. (2): 


$$
\Delta H=C_{S} \cdot \frac{H}{1+e_{0}} \cdot \log \left(\frac{K \cdot \sigma_{\mathrm{f}}}{{ }_{10}\left(\frac{{ } p t}{C_{S}} \Delta w\right)}\right)
$$

In this equation $\Delta w$ is the moisture change- and $K$ is a correction coefficient. The authors collected information from numerous expansive soil tests in order to correlate $K, C_{\mathrm{s}}$ and $I_{\mathrm{pt}}$ with the plasticity index $\left(I_{\mathrm{p}}\right)$. More recently, Tu and Vanapalli (2016) improved the model, including the relationship between deformation and the soil water content curves (SWCC) of expansive soils from diferent locations.

Puppala et al. (2014) developed a very simple model to predict the swelling or shrinkage deformation experienced by a clayey soil in response to moisture content change. Their method, based on previous work by Kodikara and Choi (2006), established a linear relationship between the axial, radial and volumetric strains and the water content change:

$$
\varepsilon_{\text {swell-shrink }}=-\alpha \cdot \Delta w
$$

where $\varepsilon_{\text {swell-shrink }}$ is the swelling or shrinkage deformation (volume, axial or radial), $\alpha$ is a proportionality coefficient and $\Delta w$ is the gravimetric moisture change.

To validate the model, Puppala et al. (2014) analysed the displacements measured at various sites in Texas (USA), comparing the results obtained using Eq. 5 with commonly used models for the prediction of deformation such as Lytton (1977) and also with a finite element (FEM) solution. The model produced similar results to the FEM simulation and both of them showed acceptable agreement with the measured deformations.

Despite the wealth of available simple methods in the literature to predict the volume change of expansive soils, the majority of them cannot be used in all geotechnical situations, due to some limitations: (a) most are valid for swelling, but not for shrinkage or collapse; (b) almost all use disturbed samples, instead of undisturbed samples; and (c) most do not consider a wide range of vertical pressures. In Table 1, a synthesis of the main characteristics of the 1-D methods analysed is presented.

Alonso et al. (1989) proposed a very complete 3-D formulation for unsaturated soils of low activity, the BBM method that has won wide acceptance. Later Gens and Alonso (1992) extended it to the behaviour of unsaturated expansive clays; the authors state that "it is likely that as further and more compprehensive experimental data become available more complex versions of the framework will have to be used". Both 
methods lead to very sophisticated constitutive models based upon plenty of constants and experiments that were mostly carried out on compacted soils. They are models that should be used in very important geotechnical engineering situations, but the simplified method presented here may be used in many cases with sufficient level of accuracy.

The research presented in this paper aims to develop a simplified model to predict the deformational behaviour under oedometric conditions of the Guadalquivir blue marl. The model proposed is valid for the simulation of simple swelling, shrinkage and collapse conditions. It has been derived empirically with tests on undisturbed samples, applying a wide range of vertical pressures. The method has been validated with experimental results in suction-controlled oedometer cells.

These characteristics of the new model, prediction of swelling, shrinkage and collapse strains, use of undisturbed samples and application of different vertical loads, have not been considered in any of the simplified models analysed in Table 1.

\section{Soil characterisation. Physical, chemical and hydraulic properties}

The undisturbed samples used in this research were obtained from rotary boreholes located at different sites in the Guadalquivir river valley. The samples were collected from the zone of depth 5 to $35 \mathrm{~m}$ of the sites, which is the depth range of interest for engineering projects. The borehole locations are indicated in in Fig. 1.

The use of undisturbed samples results in a greater dispersion of the experimental data, but provides more accurate information about the real behaviour of the natural soil. Preserving the moisture content and inner structure of the blue marl samples was considered crucial in this study because the shrink and swell behaviour of this type of soil is known to depend greatly on its microstructure (Tsige 1999).

The physical characterisation of the blue marl was done through the following tests: 76 natural moisture contents, 67 dry unit weights, 36 unit weights of solid particles, 33 Atterberg limits, 36 wet sieving and 10 sedimentation analyses. The average results of the laboratory tests are shown in Table 2.

The soil was classified as high plasticity clay with $\mathrm{CH}$ classification according to the Unified Soil Classification System (USCS). The average soil properties shown in Table 2 are within the range of the values obtained by other authors for undisturbed samples of blue marl (Tsige 1999; Alonso and Gens 2006a; 
Galera et al. 2009). It can be observed that the dispersion of physical properties is not very high, which allows considering the Guadalquivir blue marl as a single geotechnical unit.

The chemical and mineralogical composition of the soil are presented in Table 3. The samples showed a high carbonate content, with an average value of $30.6 \pm 2.8 \%$. The mineralogical composition of the samples was determined by X-ray diffraction analysis. An oriented-aggregate analysis was used to differentiate the constituent minerals of the phyllosilicates.

The phyllosilicates species found in the marl samples are smectite, illite and kaolinite. The percentage of smectite (showing the highest dispersion in Table 3) is greater in areas near the soil surface and tends to diminish at higher depths, reaching a sustained value of around $2 \%$ at depths of around 35 meters. As for the rest of the phyllosilicates, their content remains approximately constant with depth.

The carbonate content increases slightly with depth and shows similar values to the ones reported by Galera et al. (2009) for depths of up to $100 \mathrm{~m}$. As the soil dries, the carbonate particles tend to migrate from the inside of the sample towards the surface, where they precipitate forming nodules.

The content of calcite, quartz and dolomite remain constant with depth. The soil plasticity varies slightly with depth, reaching plasticity index values between 30 and 34 (Galera et al. 2009).

The microstructure of the blue marl has been analysed by the scan electron microscopy technique (SEM) and by mercury intrusion porosimetry (MIP) (Vázquez-Boza et al., 2014), showing a flocculated matrix where a macro and a microstructure can be clearly differentiated. In Fig. 2 and Fig. 3, two types of pores can be observed: intra-aggregate pores, with a size of 0.02 microns, and inter-aggregate pores, with sizes around 200 microns.

The relationship between gravimetric moisture and suction was established through the soil water characteristic curve (SWCC) of the soil. The points of the SWCC were obtained experimentally, using (a) the pressure membrane method for lower suction values $(<1,000 \mathrm{kPa})$ (Richards 1941; Bocking and Fredlund 1980) and (b) the dew point psychrometer for suctions greater than 1,000 kPa (Gee et al. 1992; Bullut et al. 2002; Leong et al. 2003). A single curve (Fig. 4) was obtained using samples from different sites. Then, the curve was approximated with a mathematical model.

The initial suction was measured with the filter paper method, according to ASTM D5298-94 (1994). Seven different measurements, from a single site (site A) and different depths, yielded an average value of $\Psi_{0}=850 \mathrm{kPa}$ with little scattering. The points in the SWCC curve were obtained from samples with the initial suction that were then subjected to wetting and drying paths. 

soil, although in some cases (e.g., Van Genuchten, 1980) the procedure to determine the parameters required has been considerably complex. By contrast, the method presented by Fredlund and Pham (2006) is simpler to implement and provides a good agreement with experimental data. For these reasons, this has been the method selected to obtain the SWCC of the Guadalquivir blue marl.

In this model, the SWCC was approximated by three straight lines that fitted the experimental data in the zones of low, medium and high suction respectively (Eq. 6).

$$
\begin{array}{ll}
w_{1}(\Psi)=w_{\mathrm{u}}-S_{1} \cdot \log (\Psi) & 1 \leq \Psi<\Psi_{\mathrm{aev}} \\
w_{2}(\Psi)=w_{\mathrm{aev}}-S_{2} \cdot \log \left(\Psi / \Psi_{\mathrm{aev}}\right) & \Psi_{\mathrm{aev}} \leq \Psi<\Psi_{\mathrm{r}} \\
w_{3}(\Psi)=S_{3} \cdot \log \left(10^{6} / \Psi\right) & \Psi_{\mathrm{r}} \leq \Psi \leq 10^{6} \mathrm{kPa}
\end{array}
$$

$$
\text { Where } w_{\mathrm{u}} \text { is the saturation moisture, } w_{\mathrm{aev}} \text { and } \Psi_{\mathrm{aev}} \text { are the air entry point moisture and suction, } \Psi_{\mathrm{r}} \text { is the }
$$
residual suction and $S_{1}, S_{2}, S_{3}$ are three linearity coefficients.

For the Guadalquivir blue marl, the parameters of Eq. (10) take the following values: $w_{\mathrm{u}}=31 \%, w_{\mathrm{aev}}=$ $29 \%, \Psi_{\mathrm{aev}}=180 \mathrm{kPa}, w_{\mathrm{r}}=4.1 \%$ and $\Psi_{\mathrm{r}}=80 \mathrm{MPa}$. Replacing these values in Eq. (6), the linearity coefficients $S_{1}, S_{2}$ and $S_{3}$ are obtained. In this way, the Fredlund and Pham (2006) formulation is particularised to the case of the Guadalquivir blue marl as follows:

$$
\begin{array}{ll}
w_{1}(\Psi)=35-2.66 \cdot \log (\Psi) & 1 \mathrm{kPa} \leq \Psi<180 \mathrm{kPa} \\
w_{2}(\Psi)=29-9.4 \cdot \log (\Psi / 180) & 180 \mathrm{kPa} \leq \Psi<80000 \mathrm{kPa} \\
w_{3}(\Psi)=3.74 \cdot \log \left(10^{6} / \Psi\right) & 80000 \mathrm{kPa} \leq \Psi \leq 10^{6} \mathrm{kPa}
\end{array}
$$

In Fig. 4, the experimentally measured values of water content and suction are compared with those obtained from Eq. (7).

\section{Experimental investigations and results}

\section{Shrink-swell test}


The shrink-swell test combines the outcomes of two tests: a core shrinkage test and a swelling under load test (Mitchell and Avalle 1984; Cameron 1989; Fityus et al. 2005).

The core shrinkage test is performed on an undisturbed cylindrical sample with a diameter of 45 to 50 $\mathrm{mm}$ and a height of 1.5-2 diameters. The test specimen is initially measured and weighed before being subjected to an air-drying process until its weight has stabilised. During this process the specimen is measured and weighed periodically. After finishing the air drying process, the sample is oven dried at a temperature between $105^{\circ}$ and $110^{\circ}$. After at least 24 hours, the sample is again measured and weighed to determine the maximum volume loss and dry weight. This procedure allows obtaining the initial moisture content and the moisture content associated with each of the volume measurements taken during the process.

The swelling test is also performed on an undisturbed sample, placed in an oedometric ring of 45-50 $\mathrm{mm}$ diameter and $20 \mathrm{~mm}$ height. The ring is mounted in a conventional oedometer with porous plates at the top and bottom of the sample, and loaded with $25 \mathrm{kPa}$ vertical pressure. Thereafter, the sample is flooded. After 24 hours, the swelling strain is measured. The moisture contents at the beginning and the end of the test are determined.

The outcomes of the shrink-swell test, shown in Fig. 5, are a combination of the shrinking strains and 
proposed in this paper, which will enable predicting the deformational behaviour in response to suction change of this type of plastic soil with a high carbonate content.

\section{Suction-controlled oedometer tests}

The volumetric behaviour in oedometric conditions of the blue marl samples was investigated with an oedometer cell (Fig. 6) designed in the Polytechnic University of Catalonia (Hoffmann et al. 2005). This cell allows imposing suction on the soil specimen by means of the axis translation, osmosis and vapour transfer techniques.

In the oedometer tests performed in this study the vapour transfer technique was chosen, using an $\mathrm{NaCl}$ solution for low suctions and a $\mathrm{CaCl}_{2}$ solution for high suctions. A diaphragm pump was used to force vapour recirculation in the closed-loop (Villar 2000; Tang and Cui 2005). The experimental setup is shown in Fig. 6. All tests were carried out in a chamber at a temperature of $20 \pm 0.5^{\circ} \mathrm{C}$ and a controlled humidity of $70 \pm 5 \%$.

Due to the low permeability of the soil, the time to achieve suction equilibrium was very long. To estimate the equilibrium time, four undisturbed marl samples were tested in a pressure membrane apparatus. Two samples were wetted from the initial suction to a suction of $400 \mathrm{kPa}$, while the other two were dried from the initial suction to a suction of $1000 \mathrm{kPa}$. During the process, the samples were weighed periodically (every two days) until a steady value of the weight indicated that the suction equilibrium had been reached. The average equilibrium time for both the wetting and the drying paths was found to be 13 days. Nevertheless, a minimum duration of 15 days was established for the suction-controlled oedometric tests in order to guarantee that the suction equilibrium is indeed achieved.

The experimental programme carried out in the suction-controlled oedometer, including the applied suctions and pressure values, is shown in Table 5. The suction was applied at the beginning of each test and maintained during the test when the pressure changes were imposed. All the tests were performed on different samples of blue marl extracted from the same borehole, at a depth of $18 \mathrm{~m}$.

The test results are shown in Fig. 7. It can be observed that the material becomes stiffer when the suction is increased, while for suctions lower than the initial suction the soil shows a clear expansive behaviour (tests EDO-SUC-1, EDO-SUC-2 y EDO-SUC-3). 
For suctions under the initial suction the samples experienced swelling strains when the pressure applied was lower than $100 \mathrm{kPa}$. This value of the vertical pressure is very close to the swelling pressure of the material $(75 \mathrm{kPa})$ that was determined through an oedemeter test according to UNE 103602:1996.

\section{Model for 1D volumetric deformation}

From the results of the suction-controlled oedometer tests a correlation can be established between the volumetric deformation (under oedometric conditions) and the suction change (in a logarithmic scale) for the different values of vertical pressure applied in the tests.

Fig. 8 plots the evolution of the volumetric strain against the logarithm of the normalised suction $\left(\Psi_{\mathrm{f}} / \Psi_{0}\right)$, where $\Psi_{\mathrm{f}}$ and $\Psi_{0}$ are the final and initial suctions respectively for each vertical pressure applied. The data have been obtained from Fig. 7 and Table 5. This figure shows the idealized trajectories corresponding to the two vertical pressures of 50 and $400 \mathrm{kPa}$ (that can be extrapolated to the rest of the vertical pressures), corresponding to the patterns of behaviour described in the following paragraphs.

It can be observed that for suctions under a certain limit, the strain remains constant. This limit coincides with the point called the swell limit $\left(w_{\mathrm{sw}}\right)$ in the shrink-swell test. For the Guadalquivir blue marl this point represents an average water content of $32.6 \%$, which corresponds to a suction of $\Psi_{\mathrm{sw}} \sim 10 \mathrm{kPa}$ according to the SWCC (Fig. 4).

In the high suction range, all the tested samples have experienced shrinking strains, that stabilise after a certain limit value of the suction. The soil water content corresponding to the final shrinking strain coincides with the shrink limit $\left(w_{\text {sh }}\right)$ calculated in the shrink-swell test. The average value of $w_{\text {sh }}$ in the soil specimens tested was 5.2\%, which corresponds to a suction of $\Psi_{\mathrm{sh}} \sim 80 \mathrm{MPa}$ (Fig. 4).

In the intermediate range of suctions between the swell and the shrink limit the soil strain is approximately proportional to the logarithm of suction, following a linear relationship that can be fitted with Eq. (1). The slope of this relationship corresponds to the instability index $\left(I_{\mathrm{pt}}\right)$ in the Aitchison model. The values of $I_{\mathrm{pt}}$ obtained empirically for the different pressures applied in the oedometer tests are listed in Table 6. If $I_{\mathrm{pt}}$ is drawn as a function of the the applied vertical pressure, a clear correlation can be observed, which can be modeled as a linear regression (Fig. 9a). From this figure, the swelling pressure $p_{\mathrm{s}}=149 \mathrm{kPa}$ is the vertical pressure corresponding to a zero instability index, and so to no volume change under suction changes. In Figure 9b, the value of the instability index has been drawn in a more compact form as indicated in eq. (8): 
$I_{p t}\left(\sigma_{\mathrm{vf}}\right)=C \log \left(\frac{p_{s}}{\sigma_{v \mathrm{f}}}\right)$

where $C$ is a constant. For this particular soil $C=0.023$ and $p_{\mathrm{s}}=149 \mathrm{kPa}$.

The volumetric deformation under oedometric conditions can be expressed as:

$$
\varepsilon_{v}\left(\Delta \sigma_{\mathrm{v}}, \Delta \Psi\right)=\varepsilon_{\mathrm{v}}\left(\Delta \sigma_{v}, \Psi_{0}\right)+\varepsilon_{v}\left(\sigma_{v f}, \Delta \Psi\right)
$$

where $\varepsilon_{v}\left(\Delta \sigma_{v}, \Delta \Psi\right)$ is the deformation corresponding to a simultaneous increment of vertical pressure $\left(\Delta \sigma_{v}\right)$ and suction $(\Delta \Psi) ; \varepsilon_{\mathrm{v}}\left(\Delta \sigma_{\mathrm{v}}, \Psi_{0}\right)$ is the deformation caused by an increment of vertical pressure while keeping the suction constant $\left(\Psi_{0}\right)$; and $\varepsilon_{v}\left(\sigma_{\mathrm{vf}}, \Delta \Psi\right)$ is the deformation experienced when an increment of suction is applied at constant vertical pressure $\left(\sigma_{v \mathrm{f}}\right)$.

The value of $\varepsilon_{v}\left(\Delta \sigma_{v}, \Psi_{0}\right)$ is normally obtained from suction-controlled oedometer tests. However, as a first approximation, it can be estimated from a conventional eodometer test, maintaining the water content of the sample constant to avoid drying as much as possible.

According to Eq. (1), $\varepsilon_{\mathrm{v}}\left(\sigma_{v f}, \Delta \Psi\right)$, can be calculated as follows:

$$
\varepsilon_{v}\left(\sigma_{v f}, \Delta \Psi\right)=I_{p t}\left(\sigma_{v f}\right) \cdot \log \left(\frac{\Psi_{\mathrm{f}}}{\Psi_{0}}\right)
$$

The volumetric strain will be swelling when $I_{\mathrm{pt}}>0$ and $\Psi_{\mathrm{f}}<\Psi_{0}$

There will be shrinkage when $I_{\mathrm{pt}}>0$ and $\Psi_{\mathrm{f}}>\Psi_{0}$

The volumetric strain will be collapse when $I_{\mathrm{pt}}<0$ and $\Psi_{\mathrm{f}}<\Psi_{0}$

$$
\varepsilon_{v}\left(\sigma_{v f}, \Delta \Psi\right)=C \log \left(\frac{p_{s}}{\sigma_{\mathrm{vf}}}\right) \cdot \log \left(\frac{\Psi_{\mathrm{f}}}{\Psi_{0}}\right)
$$

Thus, the expression to calculate the volumetric deformation (under oedometric conditions) of the Guadalquivir blue marl in the range of suctions between the swelling $\left(\Psi_{\mathrm{sw}}\right)$ and the shrinking limit $\left(\Psi_{\mathrm{sh}}\right)$ is obtained substituting Eq. (11) into Eq. (9): 


$$
\varepsilon_{v}\left(\Delta \sigma_{v}, \Delta \Psi\right)=\varepsilon_{v}\left(\Delta \sigma_{v}, \Psi_{0}\right)+C \log \left(\frac{p_{s}}{\sigma_{\mathrm{vf}}}\right) \cdot \log \left(\frac{\Psi_{\mathrm{f}}}{\Psi_{0}}\right)
$$
corresponding to the shrink limit:

$$
\varepsilon_{v}\left(\Delta \sigma_{v}, \Delta \Psi\right)=\varepsilon_{v}\left(\Delta \sigma_{v}, \Psi_{0}\right)+C \log \left(\frac{p_{s}}{\sigma_{\mathrm{vf}}}\right) \cdot \log \left(\frac{\Psi_{s h}}{\Psi_{0}}\right)
$$

$$
\varepsilon_{v}\left(\Delta \sigma_{v}, \Delta \Psi\right)=\varepsilon_{v}\left(\Delta \sigma_{v}, \Psi_{0}\right)+C \log \left(\frac{p_{s}}{\sigma_{\mathrm{vf}}}\right) \cdot \log \left(\frac{\Psi_{s w}}{\Psi_{0}}\right)
$$

The practical application of this method to the case of the Guadalquivir blue marl requires as the input its simplicity makes it very appropriate for use in geotechnical engineering applications.

\section{Discussion}

The model simulates swell, shrink and collapse behaviour of undisturbed samples at different conditions of vertical deformation and suction change under oedometric conditions.

For the range of suctions between the swell limit and the shrink limit, the relationship between out by Escario and Sáez (1973), Kassif et al. (1973), Justo et al. (1984), Richards (1984), Mitchell and 
Avalle (1984), Delgado (1986) and McKeen (1992). According to Pile and McInnes (1984), based on volume change it might be expected that $I_{\mathrm{pt}}$ for the wetting-up test in the oedometer will be three times that for the drying test in samples without lateral restrain. In practice it has been found that the ratio is less than 2, and apparently depends on the extent of small fissures in the fiels samples, which close up during oedometer testing.

For suctions outside of this range the soil deformations are nearly constant. This trend for low suctions

\section{Conclusions} and expansive soil is glimpsed in the paper by McKeen (1992), and for collapsing soils in the paper by Vázquez et al. (2013).

For a particular site (site A), the same equations have acceptably fitted the results corresponding to depths ranging from 6.6 to $21 \mathrm{~m}$ (Table 4). This is because, at this site, the scattering of the initial suction $\Psi_{0}$ was small and an average value of $850 \mathrm{kPa}$ could be used without a loss of accuracy. The same assertion is true for the swell limit. When there are important differences in these and other parameters, it will be better to consider different layers in the calculation.

In this paper, the trends hinted in several papers have been collected in a single model. As can be seen in Figure 10, the volumetric deformation calculated with the proposed model approximates the experimental results from suction-controlled oedometer tests with an acceptable acccuracy.

In this paper we analysed the volumetric behaviour under oedometric conditions of a high plasticity carbonate clay: the Guadalquivir blue marl. In relation to previous studies, this work contributes to a deeper understanding of the characteristics of this type of soil, especially of its deformational behaviour under suction and vertical pressure changes.

The blue marl forms the bedrock layer of the Guadalquivir river valley (Spain) and has been responsible for many accidents and much damage due to its high fragility, its expansive character and its vulnerability against moisture changes.

A comprehensive test campaign has been conducted to determine the physical and chemical properties of the blue marl, that was classified as a high plasticity clay $(\mathrm{CH})$ with a carbonate content above $25 \%$ and a high percentage of phyllosilicates, mainly illite and smectite. Analysis by scanning electron microscopy (SEM) and mercury intrusion porosimetry (MIP) allowed the characterising of its internal structure, 
revealing clear differences between its macro and microstructure. The SWCC was obtained using a dew point psychrometer for suctions greater than $1 \mathrm{MPa}$ and a pressure membrane apparatus for lower suctions.

To predict the deformational behaviour of this material, an empirical 1-D model has been proposed. The model simulates both the swell, shrink or collapse behaviour of undisturbed samples under different conditions of vertical loading and suction change. Currently, no simple model exists to predict the deformational behaviour of expansive soils that considers the range of strain, suction and vertical loading or the type of samples included in this paper.

The model is based on data from shrink-swell tests to characterise the relationship between deformation and suction change (in a logarithmic scale). It was found that for the range of suctions between the swell limit and the shrink limit this relationship is linear and the correlation ratio corresponds to the instability index $\left(I_{\mathrm{pt}}\right)$, that has been related to the applied vertical pressure through a logarithmic expression (derived by the authors).

For suctions outside of this range the soil deformations remain nearly constant.

From the results of shrink-swell tests conducted on undisturbed samples, the average value of the shrink limit was found to be $5 \%$, while the swell limit was $30 \%$. These values did not depend on the depth of sample collection.

The proposed unidimensional model was compared with experimental data from suction-controlled oedometer tests performed on undisturbed samples. The results obtained with the proposed model showed an acceptable agreement with the measured data.

\section{Acknowledgements}

The authors would like to acknowledge the financial support from the Innovation and Science Office of the Regional Government of Andalusia (Project TEP-6632) and the Spanish Ministry of Science and Innovation (grant BIA2010-20377). The English correction has been financed with the help for internationalisation granted to the IUACC through the VI Plan of Research and Transference of the University of Seville.

\section{References}

Aitchison, G.D. (1973). "The quantitative description of the stress-deformation behaviour of expansive soil. Preface to set of papers". Third International Conference on Expansive Soils, Haifa, Vol. 2, pp. 79-82. 
Alonso, E.E. and Gens, A. (2006a). "Aznalcóllar dam failure. Part 1: Field observations and material properties". Géotechnique, 56(3): 165-183.

Alonso, E.E.and Gens, A. (2006b). "Aznalcóllar dam failure. Part 3: Dynamics of the motion". Géotechnique, 56(3): 203-210.

Alonso, E.E., Gens, A. and Whight, D. (1989). "General report". $9^{\text {th }}$ European Conf. on Soil mech. and Foundatio Eng. Groundwater Effects in Geotechnical Engineering. Vol. 3. 1087-1146.

AS1289.7.1.1-1992 (1992). "Methods for Testing Soils for Engineering Purposes. Method 7.1.1: Determination of the Shrinkage Index of a Soil; Shrink Swell Index”, Standards Australia.

ASTM D5298-94 (1994). "Standard test method for measurement of soil potential (suction) using filter paper”. Annual Book of ASTM Standards, ASTM Intrenational, Philadelphia.

Bocking, K.A. and Fredlund, D.G. (1980). "Limitations of the axis translation technique". IV International Conference on Expansive Soils, Denver, 1:117-135.

Brasher, B.R., Franzmeier, D.P., Vallassi, V.T. and Davidson, S.E. (1966). "Use of Saran resin to coat natural soil clods for bulk density and water-retention measurements". Soil. Sci. pp 101:108.

Bulut, R., Hineidi, S.M. and Bailey, B. (2002). "Suction measurement filter paper and chilled mirror psychrometer". Proc. of the Texas Section American Society of Civil Engineers, Fall Meeting, Waco, 25 October.

Cameron, D.A. (1989). "Tests for Reactivity and Prediction of Ground Movement". Civil Enginering Transactions, I.E. Aust., Vol. 3, pp 121-132.

Delgado, A. (1986). "Influencia de la trayectoria de las tensiones en el comportamiento de las arcillas expansivas y de los suelos colapsables en el laboratorio y en el terreno". Ph. D. thesis, University of Sevilla, Spain.

Dhowian, A.W. (1990). "Field performance of expansive shale formation". J. of King Abdulaziz University. Engineering Sciences, 2:165-82.

Fityus, S., Smith, D.W. (1998). "A simple model for the prediction of free surface movements in swelling clay profiles". 2nd Int. Conf. on Unsaturated Soils, Beijing, China, pp 473-478.

Fityus, S.G., Cameron, D.A., Walsh, P.F., 2005. “The shrink swell test”. Geotech. Testing J., 28(1): 1-10. Fredlund, D.G. (1983). "Prediction of ground movements in swelling clays". 31st Annual Soil Mech. and Found Eng. Conf.. University of Minnesota, Minneapolis. 
Fredlund, D.G., Pham, H.Q. (2006). “A volume-mass constitutive model for unsaturated soils in terms of two independent stress variables". 4th Int. Conf.on Unsaturated Soils. ASCE, Carefree, Vol. 1, pp 105134.

Galera, J.M., Checa, M., Pérez, C., Williams, B., Pozo, V., (2009). “Caracterización de detalle de las margas azules del Guadalquivir mediante ensayos in situ y de laboratorio”. Ingeopres. 186: 16-22. ISSN 11364785.

Gee, G., Campbell, M., Campbell, G. (1992). "Rapid measurement of low soil potentials using a water activity meter". Soil Sci. Soc. Am. J. 56:1068-1070.

Gens, A., Alonso, E.E. (1992). "A framework for the behaviour of unsaturated expansive clays". Can. Geotech. J., 29: 1013-1032.

Gens, A., Alonso, E.E. (2006). "Aznalcóllar dam failure. Part 2: Stability conditions and failure mechanism”. Géotechnique, 56(3): 185-201.

Hamberg, D.J., Nelson, J.D. (1984). "Prediction of floor slab heave". 5th Int. Conf. on Expansive Soils, Adelaide, South Australia, pp 137-140.

Hoffmann, C., Romero, E., Alonso, E.E. (2005). “Combining different controlled-suction techniques to study expansive clays". Int. Symp. Advanced Exp. Unsat. Soil Mech.. Trento. Italy.

Justo, J.L., Delgado, A., Ruiz, J. (1984). "The influence of stress-path in the collapse-swelling of soils at the laboratory”. 5th Int. Conf. on Expansive Soils, Adelaide, South Australia, pp 67-71.

Kassif, G., Baker, R. and Ovadia, Y. (1973). $3^{\text {rd }}$ Int. Conf. Expansivce Soils, 1: 201-208.

Kodikara, J.K., Choi, X. (2006). “A simplified analytical model for desiccation cracking of clay layers in laboratory tests". Fourth International Conference on Unsaturated Soils. Geotechnical Special Publication, 147, pp 2558-2569.

Leong, E.C., Triphathy, S. and Rahardjo, H. (2003). "Total suction measurement of unsaturated soils with a device using the chilled-mirror dew-point technique”. Géotechnique, 53(2):173-182.

Llorente Gómez, E. (1986). “Riesgos geológicos”. Instituto Geológico y Minero de España, ISBN: 84-5057599-0.

Lytton, R.L. (1977). "Foundations in expansive soils". Numerical Methods in Geotechnical Engineering. C.S. Desai and J.T. Christian, McGraw Hill, N. Y. pp 427 - 457.

McKeen, R.G. (1980). "Field Studies of Airport Pavements on Expansive Soils". 4th International Conference on Expansive Soils, pp 242-261. 
McKeen, R.G. (1992). “A Model for Predicting Expansive Soil Behaviour”. 7th Int. Conf. on Expansive Soils, Dallas, TX, Vol. 1, pp 1-6.

Mitchell, P.W., Avalle, D.L. (1984). “A Technique to Predict Expansive Soil Movements”. 5th Int. Conf. on Expansive Soils, Adelaide, South Australia, pp 124-130.

Pile, K.C., McInnes, D.B. (1984). "Laboratory technology for messuring properties of expansive clays). 5th Int. Conf. on Expansive Soils, Adelaide, South Australia, pp 85-93.

Pousada, E. (1984). "Deformabilidad de la arcillas expansivas bajo succión controlada". Centro de Estudios y Experimentación de Obras Públicas. CEDEX. Madrid. ISBN: 84-398-2554-4.

Puppala, A.J., Manosuthikij, T., Chittoori, B.C.S. (2014). "Swell and shrinkage strain prediction models for expansive clays". Eng. Geology, 168:1-8.

Richards, L.A. (1941). “A pressure-membrane extraction apparatus for soil solution”. Soil Sci., 51:377386.

Richards, B.G. (1984). "Finite element analysis of volume change in expansive clays". 5th Int. Conf. on Expansive Soils, Adelaide, South Australia, pp 141-148.

Tang, A.M., Cui, Y.J. (2005). "Controlling suction by the vapour equilibrium technique at different temperatures and its application in determining the water retention properties of MX80 clay". Can. Geotech. J., 42: 287-296.

Tsige, M. (1999). "Microfábrica y mineralogía de las arcillas azules del Guadalquivir: influencia en su comportamiento geotécnico”. CEDEX. Ministerio de Fomento, Madrid. ISBN: 84-498-0426-4.

Tu, H., Vanapalli, S.K. (2016). "Prediction of the variation of swelling pressure and one-dimensional heave of expansive soils with respect to suction using the soil-water retention curve as a tool". Can. Geotech. J., 53: 1213-1234.

UNE 103200:1993 (1993). “Determinación del contenido de los carbonatos en los suelos”. Asociacion Española de Normalización y Certificación AENOR. Madrid.

UNE 103602:1996 (1996). "Ensayo para calcular la presión de hinchamiento de un suelo en edómetro". Asociacion Española de Normalización y Certificación AENOR. Madrid.

Van Genuchten, M.T. (1980). "A closed-form equation for predicting the hydraulic conductivity of unsaturated soils". J. Soil Science Soc. of America, 44: 892-898.

Vanapalli, S.K., Lu, L. (2012). "A state-of-the art review of 1-D heave prediction methods for expansive soils". Int J. Geotech.Eng., Vol. 6: 15-45. 
Vanapalli, S.K., Lu, L., Oh, W.T. (2010). "A simple technique for estimating the 1-D heave in expansive soils". 5th Int. Conf. Unsaturated Soils, Barcelona,Spain. September 6-8, 2010. CRC Press, Vol. 2, pp 1201-1207.

Vázquez, M., Justo, J.L., Durand, P. (2013). “A simplified model for collapse using suction controlled tests". 18th Int.Conf. on Soil Mechanics and Geotechnical Engineering, Paris, France. 2-5 September, 2013. Presses des Ponts, Vol. 1, pp 1203-1206.

Vázquez-Boza, M., Justo, J.L., Durand, P., Morales-Esteban, A. (2014). "Macro and microstructure of Guadalquivir blue marls in cyclic suction-controlled drying and wetting test”. 6th Int.Conf. on Unsat.Soils, Sydney, Australia. 2-4 July, 2014. CRC Press, Vol. 1, pp 727-732.

Villar, M.V. (2000). “Caracterización termo-hidro-mecánica de una bentonita de Cabo de Gata”. Ph.D. Thesis, Universidad Complutense de Madrid. Madrid. Spain.

Zabala, F., Alonso, E.E. (2011). "Progressive failure of Aznalcóllar dam using the material point method". Géotechnique, 61(9): 795-808. doi: 10.1680/geot.9.P.134. 
Table 1. Most widely known uni-dimensional models.

\begin{tabular}{|c|c|c|c|c|}
\hline Model & $\begin{array}{l}\text { Volumetric } \\
\text { behaviour }\end{array}$ & $\begin{array}{l}\text { Type of } \\
\text { sample }\end{array}$ & $\begin{array}{c}\text { Vertical } \\
\text { pressures range } \\
(\mathrm{kPa})\end{array}$ & Suction range \\
\hline Fredlund (1983) & Swelling & Disturbed & 7 to $p_{s}{ }^{(1)}$ & $\begin{array}{r}\Psi_{0}^{(4)} \text { to } \\
\text { saturation }\end{array}$ \\
\hline $\begin{array}{l}\text { Hamberg and } \\
\text { Nelson (1984) }\end{array}$ & $\begin{array}{l}\text { Swelling } \\
\text { Shrinkage }\end{array}$ & $\begin{array}{l}\text { Disturbed } \\
\text { Undisturbed }\end{array}$ & Not applied & $w_{\mathrm{S}}$ to $w_{\mathrm{P}}^{(3)}$ \\
\hline Dhowian (1990) & Swelling & Undisturbed & 0 to $p_{s}$ & $\begin{array}{r}\Psi_{0} \text { to } \\
\text { saturation }\end{array}$ \\
\hline $\begin{array}{l}\text { Fityus and Smith } \\
\text { (1998) }\end{array}$ & Swelling & Disturbed & $p_{\mathrm{f}}^{\prime(2)}$ & $\begin{array}{r}\Psi_{0} \text { to } \\
\text { saturation }\end{array}$ \\
\hline $\begin{array}{l}\text { Vanapalli et al. } \\
\text { (2010) }\end{array}$ & Swelling & Disturbed & $p_{\mathrm{f}}$ & $\begin{array}{r}\Psi_{0} \text { to } \\
\text { saturation }\end{array}$ \\
\hline $\begin{array}{l}\text { Puppala et al. } \\
\text { (2013) }\end{array}$ & $\begin{array}{l}\text { Swelling } \\
\text { Shrinkage }\end{array}$ & Disturbed & Not applied & $\begin{array}{r}\Psi_{\mathrm{r}}^{(4)} \text { to } \\
\text { saturation }\end{array}$ \\
\hline
\end{tabular}

${ }^{(1)} p_{s}$ : Swelling pressure.

$4 \quad{ }^{(2)} p$ ' : Effective pressure.

$5 \quad{ }^{(3)} w_{\mathrm{S}} / w_{\mathrm{P}}$ : Shrinkage and plastic limit.

(4) $\Psi_{0}, \Psi_{\mathrm{r}}$ : Initial and residual suction. 
1 Table 2. Average results of the laboratory tests: $\gamma_{\mathrm{s}}$ - unit weight of solid particles-, $\gamma_{\mathrm{d}}-$ dry unit weight$2 \quad, w$ - water content-, $w_{\mathrm{L}}$-liquid limit and $I_{\mathrm{p}}$-plasticity index-.

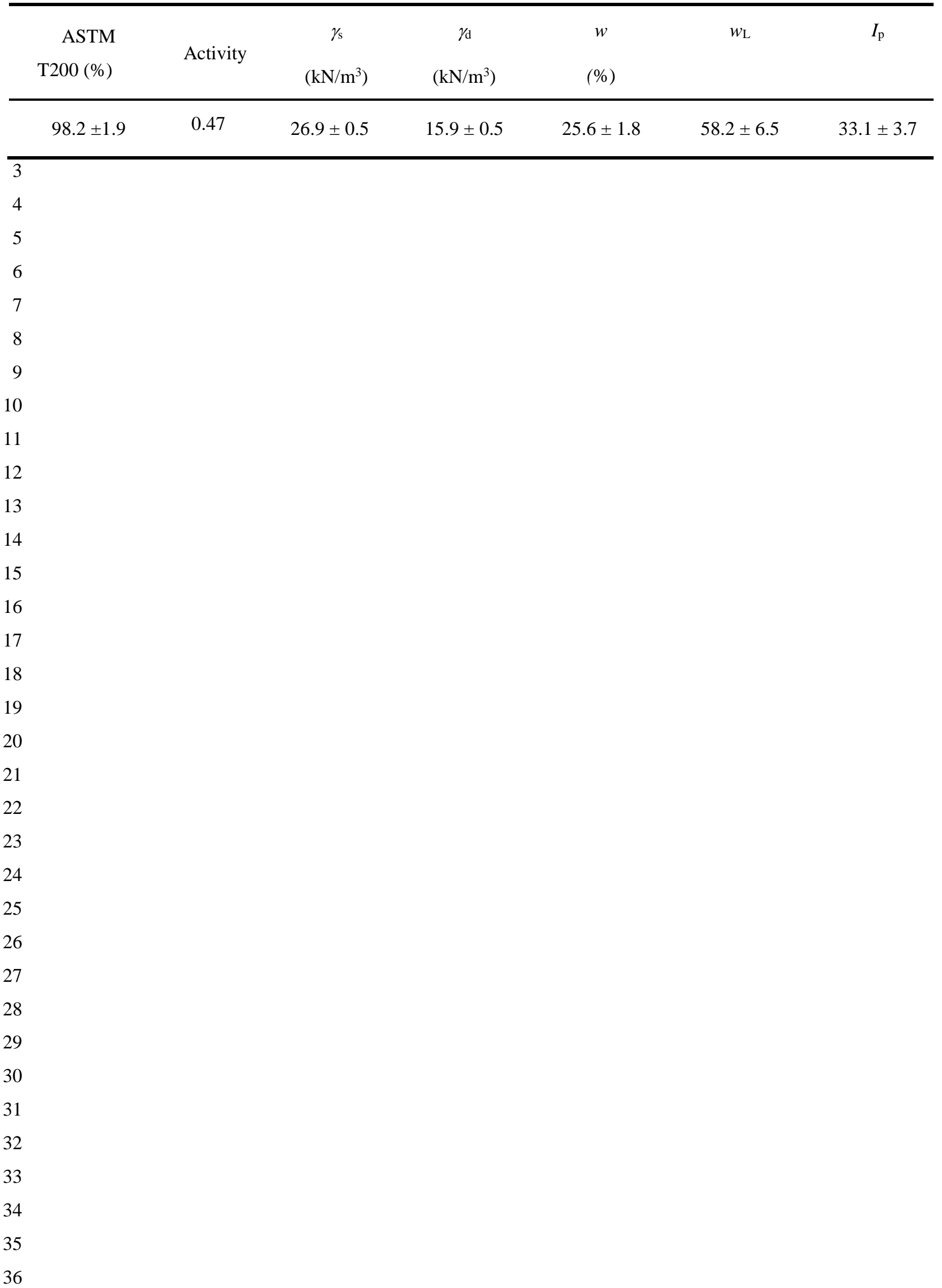


1 Table 3. Average mineralogical composition of the Guadalquivir blue marls.

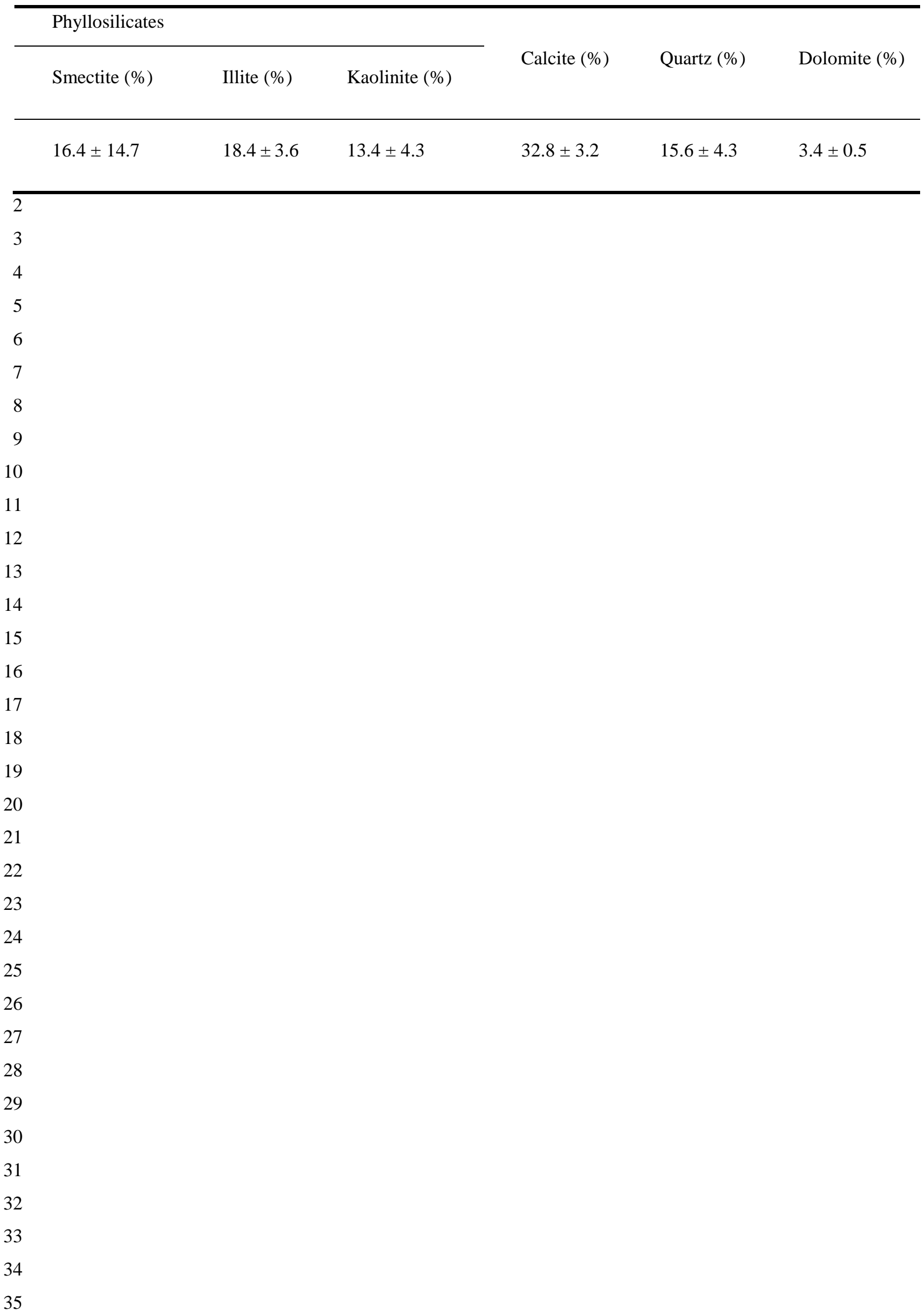


Table 4. Experimental results for Shrink-Swell Test.

\begin{tabular}{cccccc}
\hline $\begin{array}{c}\text { Depth of } \\
\text { the sample } \\
(\mathrm{m})\end{array}$ & $\begin{array}{c}w_{\mathrm{sw}} \\
(\%)\end{array}$ & $\begin{array}{c}w_{\mathrm{sh}} \\
(\%)\end{array}$ & $\begin{array}{c}\varepsilon_{\mathrm{sw}} \\
(\%)\end{array}$ & $\begin{array}{c}\varepsilon_{\text {shver }} \\
(\%)\end{array}$ & $\varepsilon_{\text {shver }} / \varepsilon_{\text {shvol }}$ \\
\hline 6.6 & 34.1 & 6.23 & 1.20 & 3.29 & 0.47 \\
\hline 6.6 & 34.0 & 7.53 & 1.04 & 4.19 & 0.61 \\
\hline 18 & 33.0 & 4.05 & 9.20 & 4.19 & 0.47 \\
\hline 21 & 32.3 & 4.21 & 3.10 & 4.59 & 0.45 \\
\hline 21 & & & & \\
\hline
\end{tabular}

3

4

5

6

7

8

9

10 
Table 5. Empirical oedometer tests.

\begin{tabular}{llll}
\hline Test & $\begin{array}{l}\text { Suction } \\
(\mathrm{kPa})\end{array}$ & Saline solution & $\begin{array}{l}\text { Vertical pressures } \\
\text { Load/Unload (kPa) }\end{array}$ \\
\hline EDO-SUC- 1 & 0 & Saturation & $10-50-100-200-400-800-1000-400-10$ \\
\hline EDO-SUC- 2 & 100 & $\mathrm{NaCl}$ & $10-50-100-200-400-800-1000-400-10$ \\
\hline EDO-SUC- 3 & 450 & $\mathrm{NaCl}$ & $10-50-100-200-400-800-1000-400-10$ \\
\hline EDO-SUC- 4 & 850 & $\mathrm{NaCl}$ & $10-50-100-200-400-800-1000-400-10$ \\
\hline EDO-SUC- 5 & 10000 & $\mathrm{NaCl}$ & $10-50-100-200-400-800-1000400-10$ \\
\hline EDO-SUC- 6 & 33100 & $\mathrm{NaCl}$ & $10-50-100-200-400-800-1000400-10$ \\
\hline EDO-SUC- 7 & 94200 & $\mathrm{CaCl} 2$ & $10-50-100-200-400-800-1000400-10$ \\
\hline
\end{tabular}

2

3

4

5

6

7

8

9 
Table 6. $I_{\mathrm{pt}}$ variation with the vertical pressure $\left(\sigma_{v}\right)$

\begin{tabular}{ll} 
Vertical pressure $\sigma_{\mathrm{v}}(\mathrm{kPa})$ & $I_{\mathrm{pt}}$ \\
\hline 10 & 0.021 \\
\hline 50 & 0.014 \\
\hline 100 & 0.007 \\
\hline 400 & -0.013 \\
\hline 800 & -0.024 \\
\hline 1000 & -0.021 \\
\hline
\end{tabular}

3 


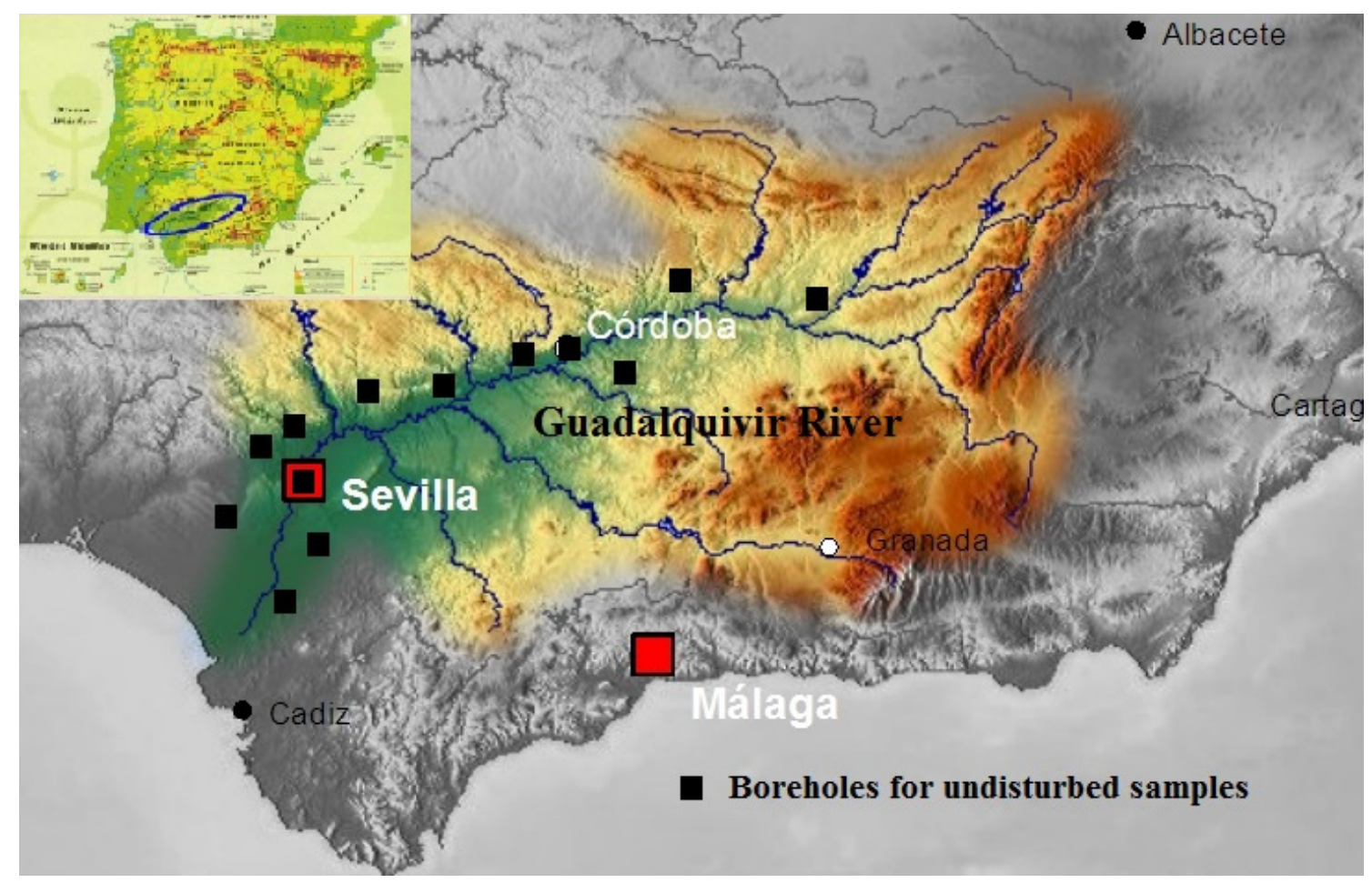




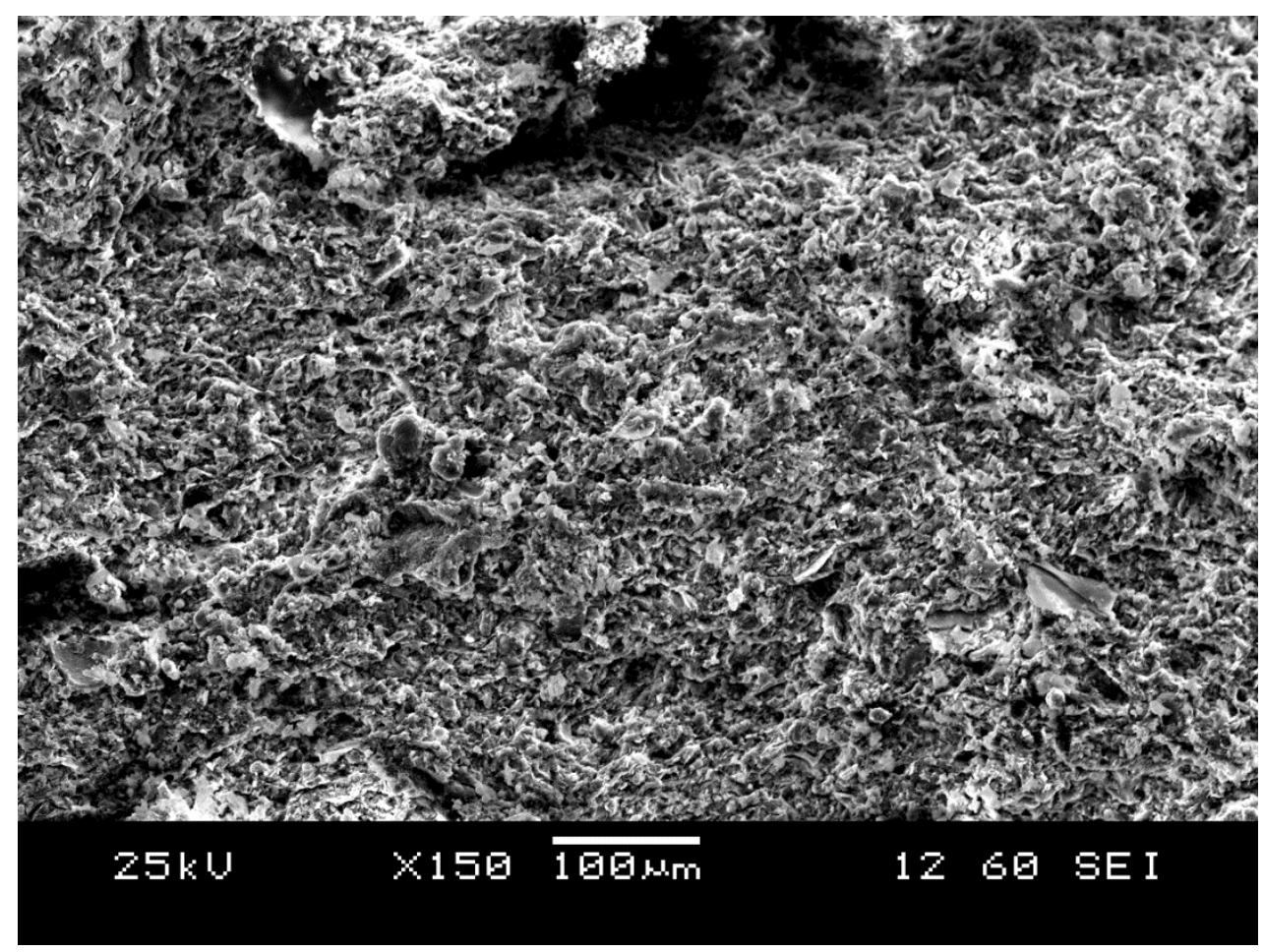




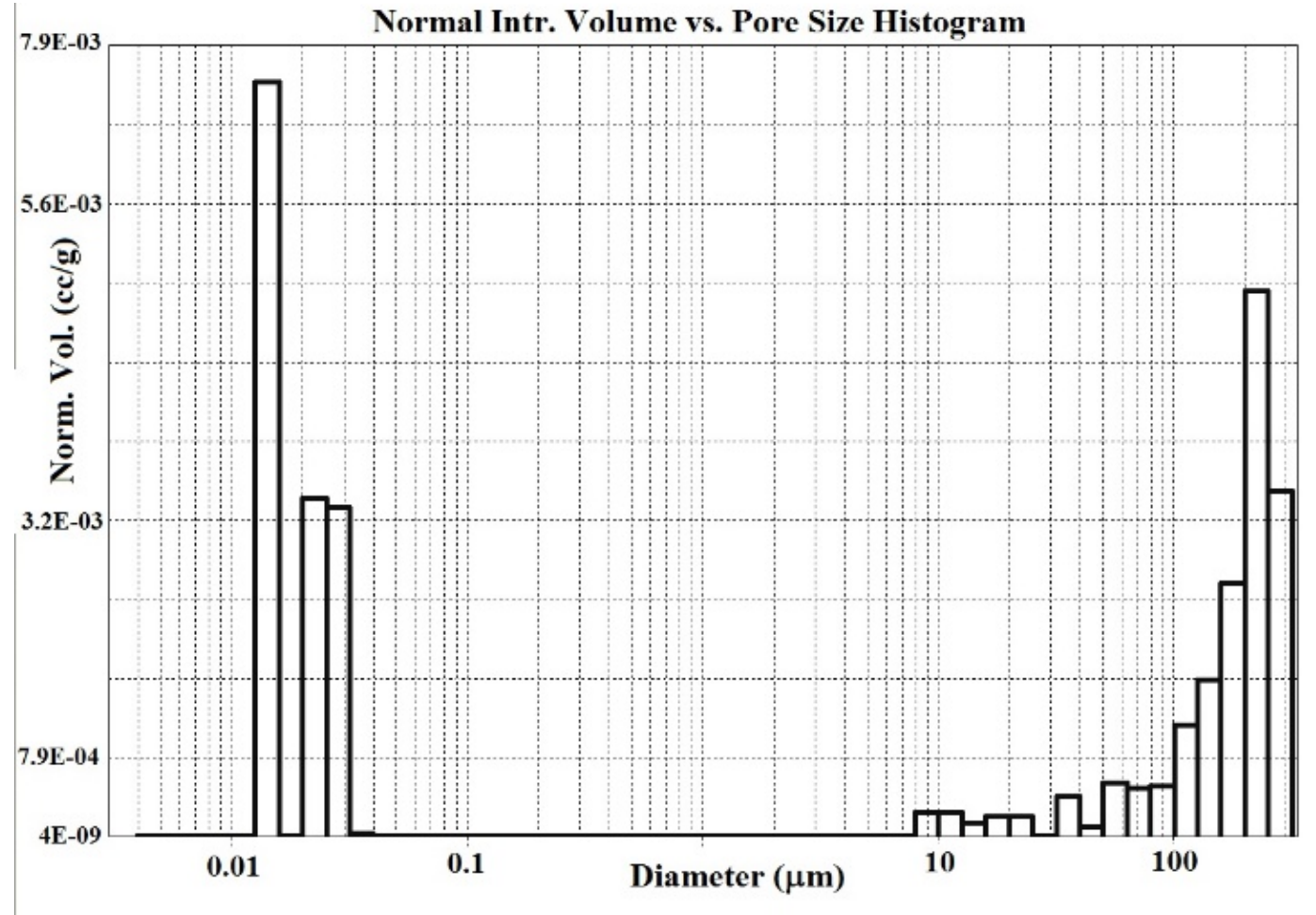




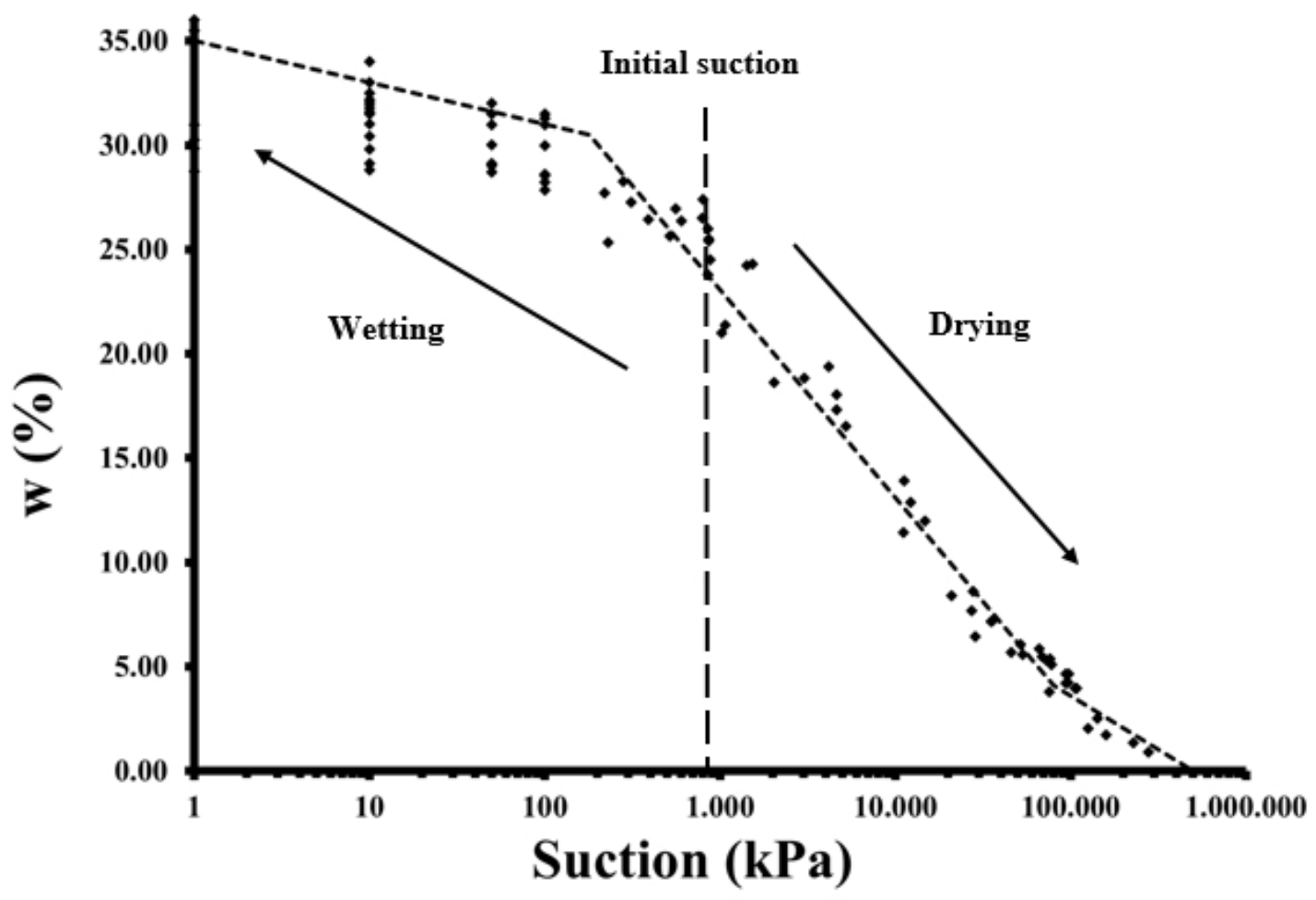




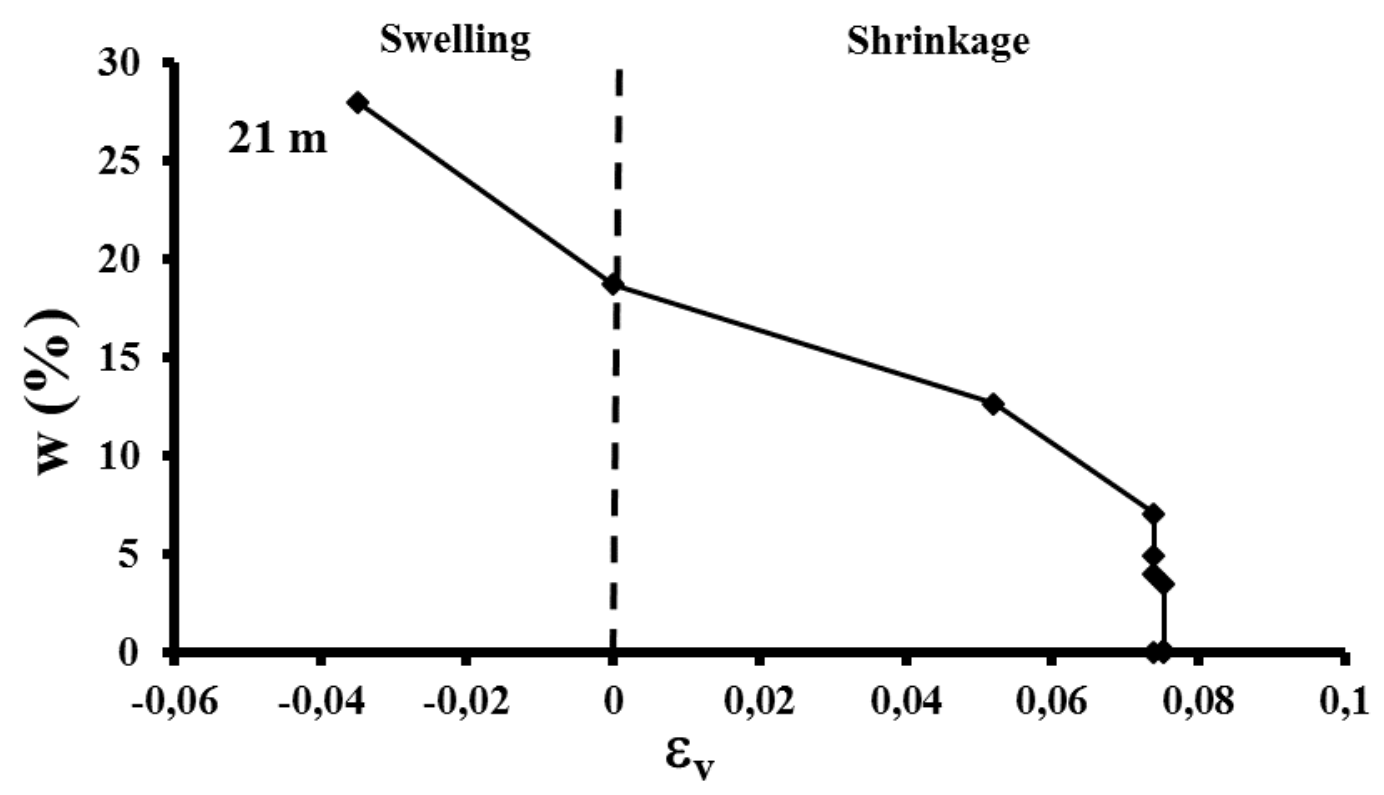




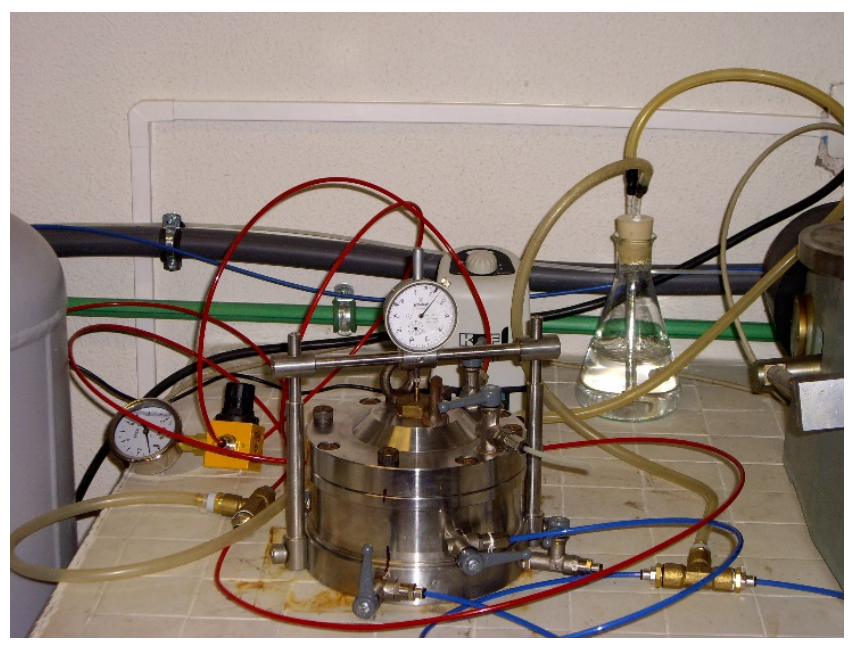




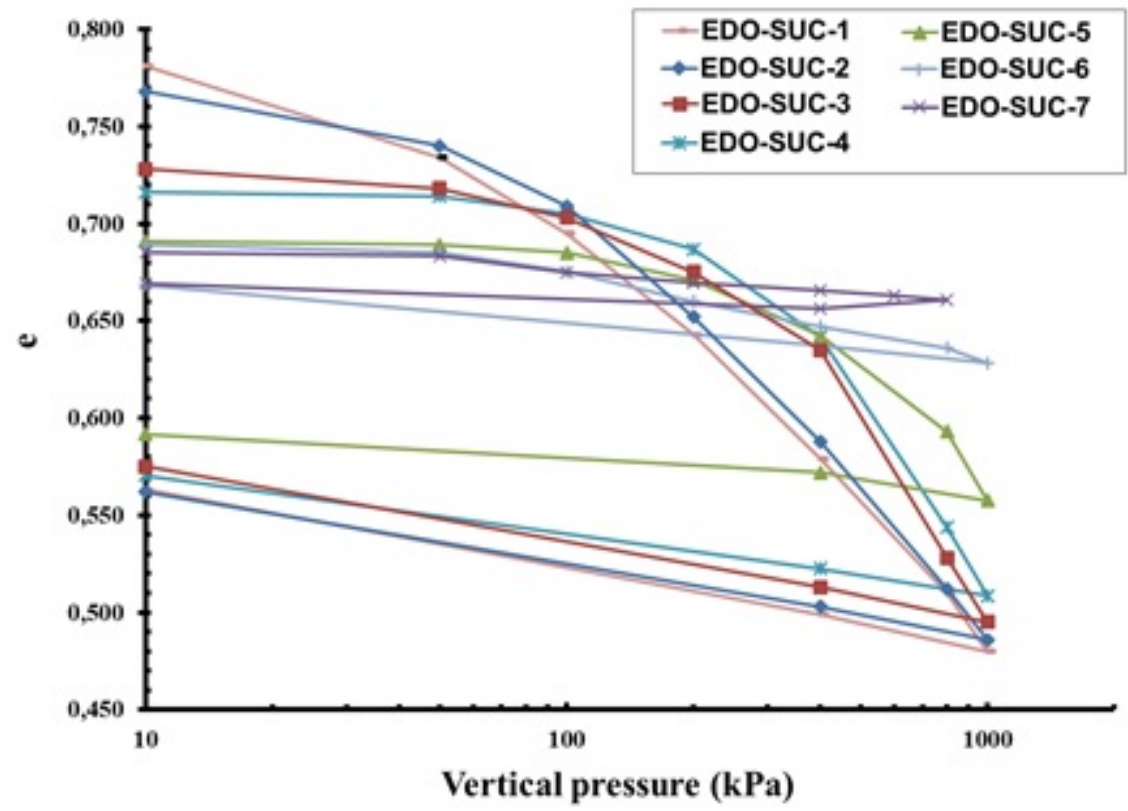




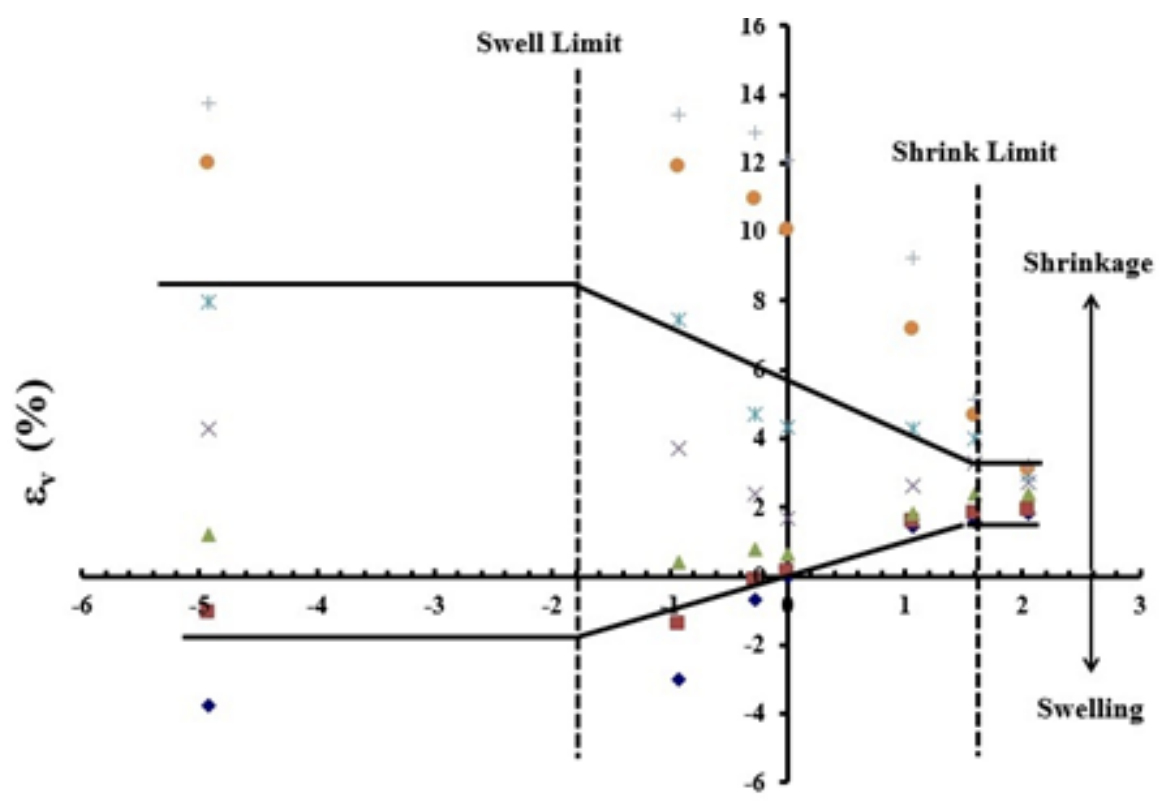

$\log \left(\Psi_{f} / \Psi_{\bullet}\right)$

Vertical pressures:

+ $10 \mathrm{kPa}=50 \mathrm{kPa}$

$100 \mathrm{kPa}$

$\times 200 \mathbf{~ k P a}$

$\times 400 \mathrm{kPa}$

- $800 \mathrm{kPa}$

$1000 \mathrm{kPa}$ 


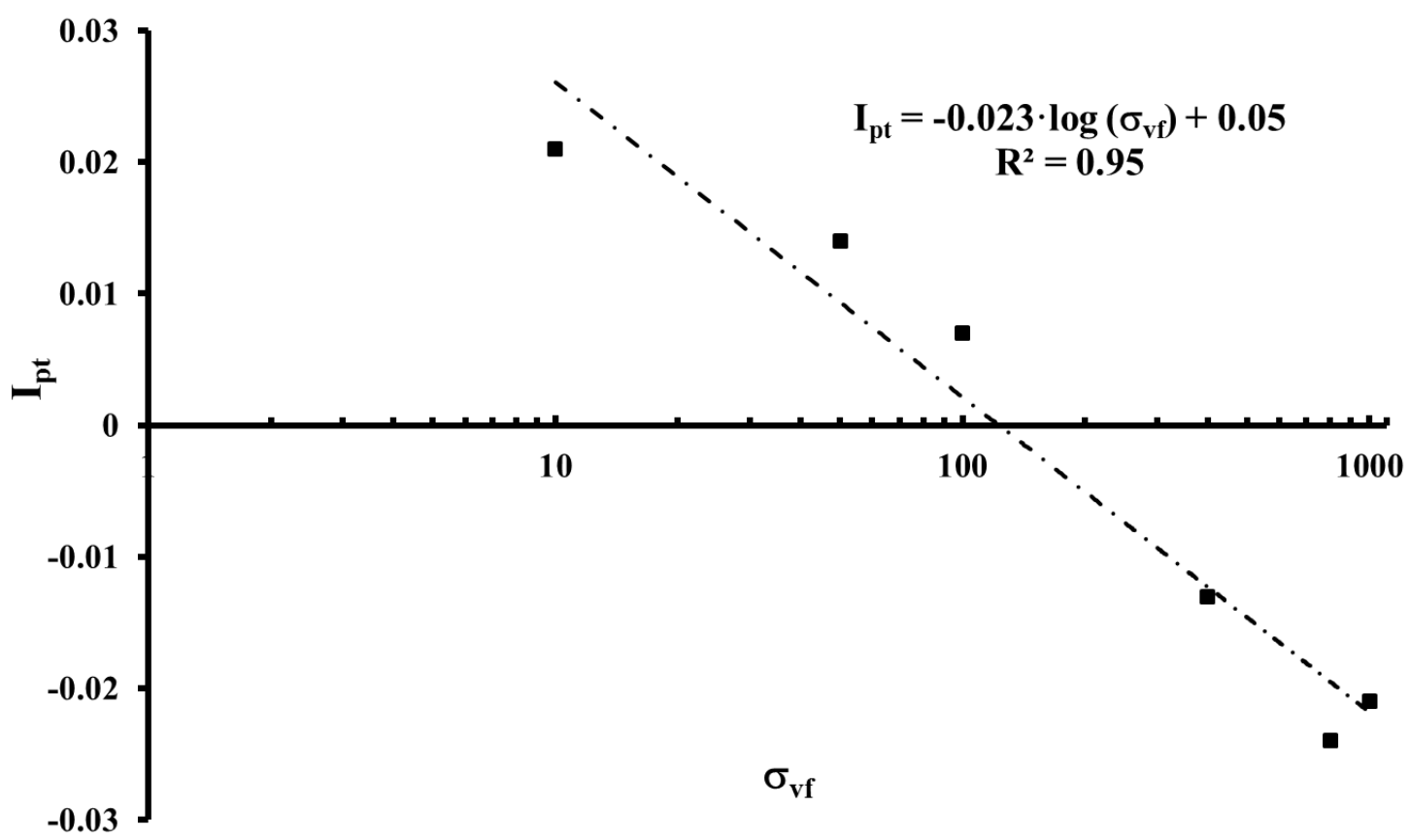

a)

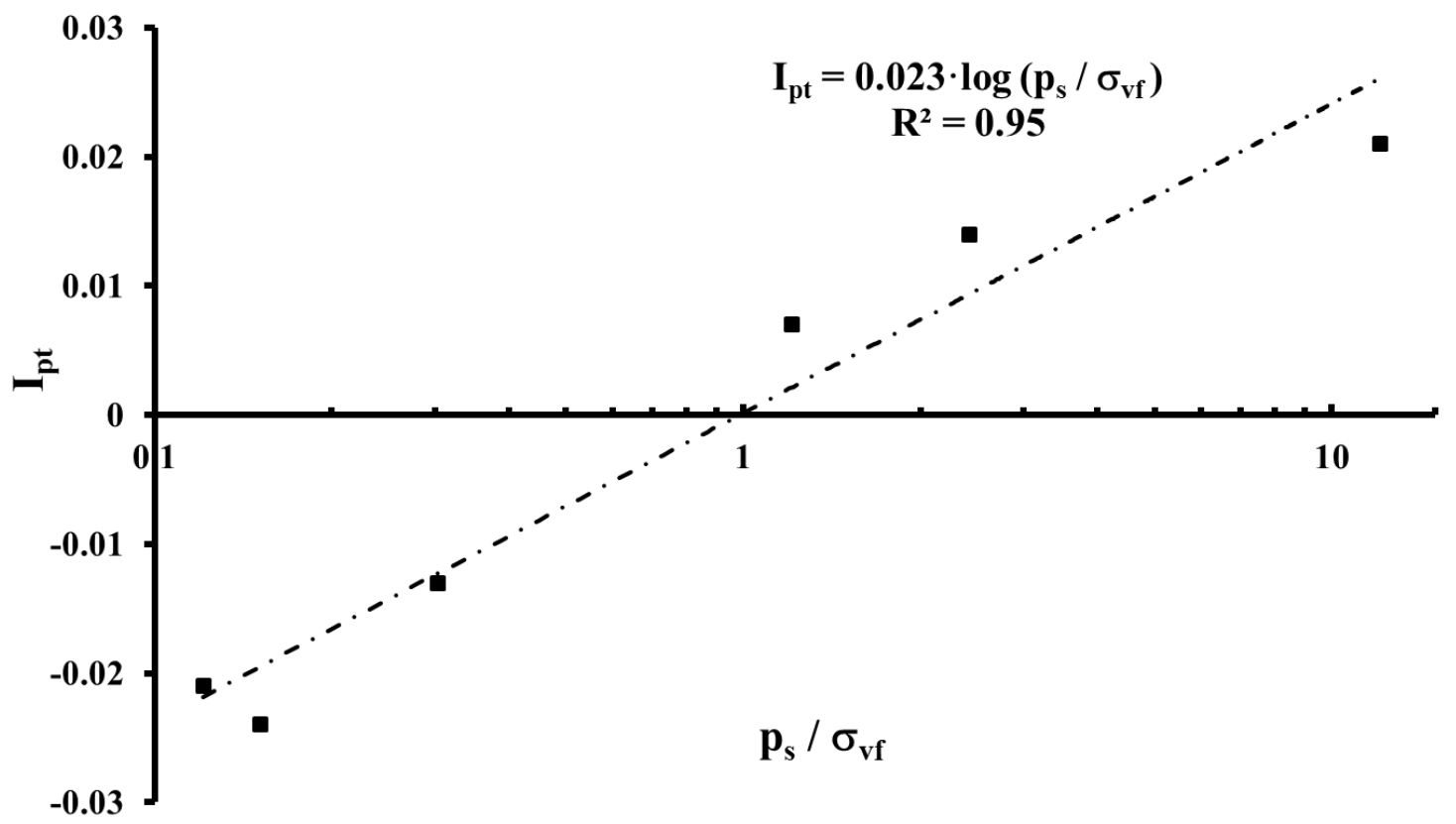

b) 


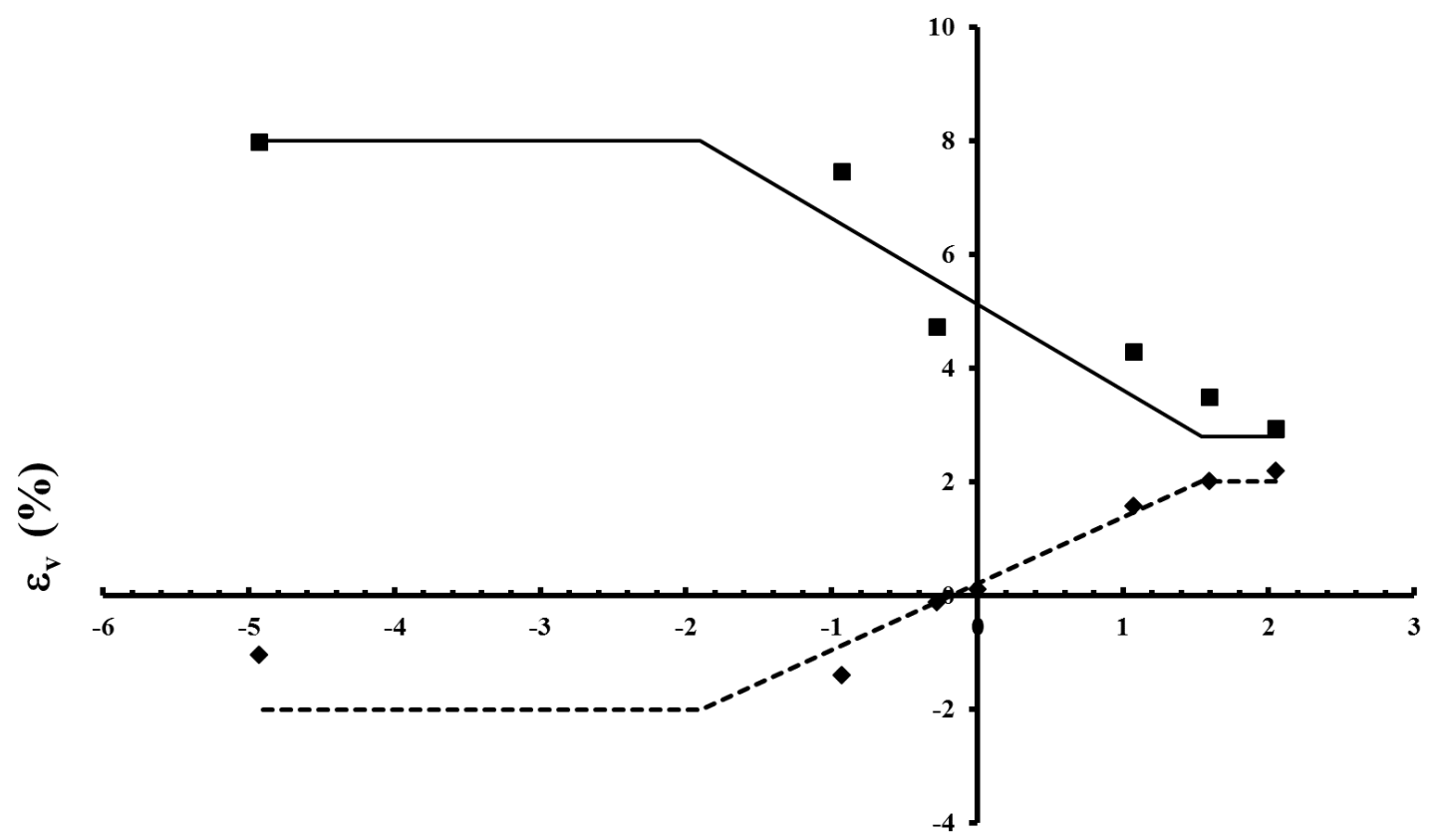

\section{$\log \left(\Psi_{f} / \Psi_{0}\right)$}

- Experimental results (vertical pressure: $50 \mathrm{kPa}$ )

- Experimental results (vertical pressure: $400 \mathrm{kPa}$ )

---Model (50 kPa)

—Model (400 kPa) 
$1 \quad$ Fig. 1. Samples location.

2

3 Fig. 2. SEM picture.x150 zoom (Vázquez-Boza et al., 2014)

4

5 Fig. 3. MIP. Pore-size distribution before the suction-controlled tests were done (Vázquez-Boza et al., 6 2014).

7

8 Fig.4. SWCC of the Guadalquivir blue marl.

9

10 Fig. 5 Shrink-Swell test results. Depth of the sample $21 \mathrm{~m}$.

Fig.6 Suction-controlled oedometer cell (Vázquez-Boza et al., 2014).

Fig. 7. Oedometer tests results.

Fig. 8 Volumetric deformation vs. suction for two vertical reference pressures (50 and $400 \mathrm{kPa}$ ).

Fig. 9. Correlations of $I_{\mathrm{pt}}$

$19 \quad$ a) $I_{\mathrm{pt}}$ as a function of $\sigma_{\mathrm{vf}}$

b) $I_{\mathrm{pt}}$ as a function of $p_{\mathrm{s}} / \sigma_{\mathrm{vf}}$

Fig. 10 Volumetric deformation vs. Suction for two vertical reference pressures. 